\title{
Effect of Grasses and Soil Properties on Wind Erosion in Sand Blowouts
}

\author{
M.J. MALAKOUTI, D.T. LEWIS, AND J. STUBBENDIECK
}

Highlight: Many areas where wind erosion has been severe exist on the sandy rangeland in northcentral and western Nebraska. These areas are called "blowouts,' and because of their large number and sometimes large size, forage production in the area is significantly reduced. It is necesary to reestablish vegetation on the blowouts in order to effectively manage the rangeland where they occur. Therefore, a study was conducted to determine the effectiveness of eight species of grass in revegetating the blowouts and in controlling wind erosion in them. The major factors related to stabilizing the soil surface in the blowouts were the amount of vegetative cover produced by the grasses and the length of time required for the protective cover to become established. In most cases the more vigorous rhizome producing grasses were most effective in becoming rapidly established and controlling wind erosion. However, none of the grasses studied were as effective in controlling wind erosion as was a mulch of prairie hay. A significant negative correlation existed between soil organic matter content and movement of sand by wind.

The Sandhills of Nebraska consists of about $52,000 \mathrm{~km}^{2}$ in northcentral and western Nebraska (Seevers et al. 1975). Throughout this region thousands of hectares of rangeland exist where vegetation has been damaged or destroyed and the sand is subject to erosion by wind. These wind-eroded areas (blowouts) sometimes are as large as 50 hectares and represent a significant loss of forage production to the area. If left unprotected, the surface of the blowout is seldom able to become vegetated, the sand moved by the wind destroys surrounding grasses, and the blowout enlarges.

Blowout formation is brought about through removal of vegetative cover by overgrazing, prairie fire, or cultivation (Seevers et al. 1975). Mulches and/or vegetation are required to stop sand movement and heal the blowout. Many attempts to control wind erosion in various regions have been reported in the literature (Bagnold 1941; Chepil and Woodruff 1963; Chepil et al. 1963; Drullinger and Schmidt 1968; Eck et al.

Authors are graduate student and associate professors of agronomy, University of Nebraska, Lincoln 68583. Dr. Malakouti is currently with the Research Institute of Forest and Rangeland, Tehran, Iran.

This report is published as Paper Number 5442, Journal Series, Nebraska Agricultural Experiment Station.
1968; Behimaya et al. 1974; Woodruff et al. 1974). In general, these methods have been an attempt to establish some type of vegetation with or without the benefit of mulches. Mulches used range from manure and prairie hay to asphalt. Chemical compounds of various kinds have been evaluated in terms of their effect on wind erosion control by some workers (Armbrust

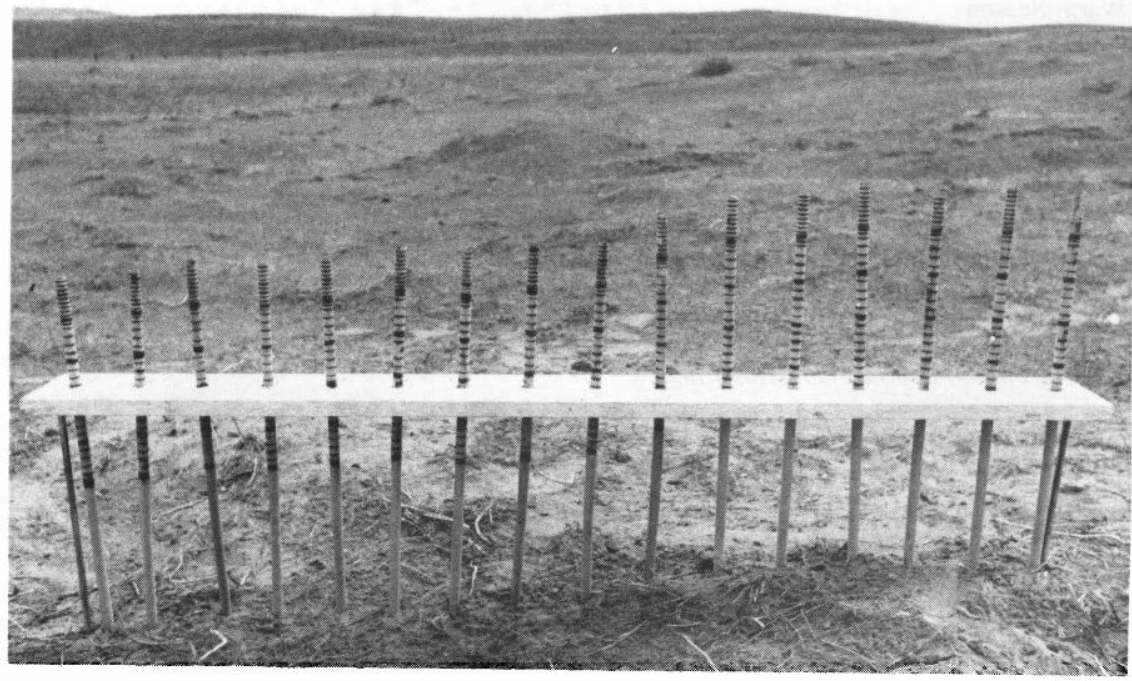

Fig. 1. Device used to measure sand movement. The calibrated dowels were inserted through the leveled board to the sand surface at the time measurements were made. Afterward, both board and dowels were removed from the two permanetly placed steel rods. and Dickerson 1971). Most researchers have reported varying degrees of success in blowout stabilization, but the degree of success is often dependent upon the type of vegetation established, the durability of the mulch, and the turbulence of the air flow across the blowout as affected by its orientation to the sand moving wind (Bagnold 1941; Baver et al. 1972).

The purpose of this study was to determine the relative effectiveness of eight grasses commonly grown in western Nebraska in revegetating blowouts and controlling sand movement. Correlation between some commonly measured soil properties and sand movement in the blown out areas was evaluated.

\section{Methods and Materials}

Twelve blowouts on the experimental range area at the University of Nebraska 
Panhandle Station near Scottsbluff were selected as sites for stabilization studies. Some of the pastures in which the blowouts were located were composed of coolseason grasses while others were composed of warm-season grasses. Since cool- and warm-season grasses are managed separately, a separate experiment to study the effect of cool- and warm-season grasses was established. In order to minimize the effect of blowout shape on air turbulence, each site was shaped by bulldozing prior to fertilization and planting. Soil samples were taken from the A horizon or top soil of soils in the blowouts, before and after shaping, and of undisturbed rangeland outside the blowouts. Sampling sites were randomly located in the blowouts, and samples were taken with a sampling tube in user sampling the soil. Major physical, chemical and mineralogical properties of these samples were determined following procedures outlined by Jackson (1956) and the Soil Survey Staff (1972).

Four warm-season and four cool-season grasses were broadcast by hand in two separate experiments (Table 1). These were placed in a randomized complete block design and replicated 5 times. Each blowout area was handled as a replicate. A plot mulched with mature prairie hay was used as a check and compared with the grasses in each replicate in each of the two experiments. Both experiments received a uniform fertilizer treatment of $20 \mathrm{~kg} / \mathrm{ha}$ nitrogen (34-0-0) and $20 \mathrm{~kg} / \mathrm{ha}$ phosphorus (0-48-0) at seeding time, April 15, 1976. After the grasses had become established, the manner usually prescribed for a land

they were fertilized with $20 \mathrm{~kg} / \mathrm{ha}$ nitrogen in the form of ammonium sulfate.

The amount of sand moved by the wind was used as an indication of the rate at which soil erosion was taking place. Sand movement was determined each month using the device shown in Figure 1. This device a $124 \times 11 \times 2.5 \mathrm{~cm}$ board with 16 holes $2 \mathrm{~cm}$ in diameter) was placed on leveled steel rods $(1 \mathrm{~cm}$ in diameter) at a randomly selected place in each plot at the time of each monthly measurement. Dowels with calibration marks were then inserted in the holes $(7.5 \mathrm{~cm}$ apart) to the level of the sand. The change in distance between the board and the surface of the sand was recorded as sand added or removed. Measurements were made montly over a 2-year period. Stand density measurements were made in August 1976 and June 1977. A $0.1 \mathrm{~m}^{2}$ frame was randomly placed at 60 locations within each plot and seedlings were counted within the frame at each location.

\section{Results and Discussion}

Stand density and frequency of occurrence as they relate to movement of sand are shown in Table 1. Among the warm-season grasses, prairie sandreed had the highest stand density and the greatest frequency of occurrence. In addition, less sand was moved in plots seeded with this species (Table 2). Only mulched plots had a lower amount of sand moved. The vigorous rhizomes

Table 1. Mean stand density (plants/ $\mathbf{m}^{2}$ ) and frequency $(\%)$ of occurence of grasses in 5 blowouts used as replicates.

\begin{tabular}{|c|c|c|c|c|}
\hline \multirow{2}{*}{ Grass Species } & \multicolumn{2}{|c|}{$\begin{array}{l}\text { Stand density } \\
\left(\text { plants } / \mathrm{m}^{2}\right)\end{array}$} & \multicolumn{2}{|c|}{$\begin{array}{l}\text { Frequency of } \\
\text { occurrence }(\%)\end{array}$} \\
\hline & 1976 & 1977 & 1976 & 1977 \\
\hline \multicolumn{5}{|l|}{ Warm Season } \\
\hline $\begin{array}{l}\text { Prairie sandreed } \\
\text { Calamovilfa longifolia Scribn. }\end{array}$ & $18.9 \mathrm{a}^{1}$ & $20.9 a$ & $58 \mathrm{a}$ & $57 a$ \\
\hline $\begin{array}{l}\text { Sand lovegrass } \\
\text { Eragrostis trichoides (Nutt.) Wood }\end{array}$ & $18.3 \mathrm{a}$ & $18.2 b$ & $56 \mathrm{~b}$ & $54 b$ \\
\hline $\begin{array}{l}\text { Sand bluestem } \\
\text { Andropogon hallii Hack. }\end{array}$ & $18.0 \mathrm{a}$ & $17.8 \mathrm{~b}$ & $55 \mathrm{~b}$ & $52 \mathrm{~b}$ \\
\hline $\begin{array}{l}\text { Little bluestem } \\
\text { Schizachyrium scoparium (Michx.) Nash. }\end{array}$ & $14.8 \mathrm{~b}$ & $12.0 \mathrm{c}$ & $55 \mathrm{~b}$ & $51 \mathrm{~b}$ \\
\hline \multicolumn{5}{|l|}{ Cool Season } \\
\hline $\begin{array}{l}\text { Intermediate wheatgrass } \\
\text { Agropyron intermedium (Host) Beauv. }\end{array}$ & $25.7 \mathrm{a}$ & $22.3 \mathrm{a}$ & $53 a$ & $51 \mathrm{a}$ \\
\hline $\begin{array}{l}\text { Western wheatgrass } \\
\text { Agropyron smithii Rybd. }\end{array}$ & $23.6 \mathrm{~b}$ & $18.3 \mathrm{~b}$ & $58 \mathrm{~b}$ & $57 \mathrm{~b}$ \\
\hline $\begin{array}{l}\text { Crested wheatgrass } \\
\text { Agropyron desertorum (Fisch.) Schult. }\end{array}$ & $19.2 \mathrm{c}$ & $12.9 \mathrm{c}$ & $53 a$ & $57 \mathrm{~b}$ \\
\hline $\begin{array}{l}\text { Indian ricegrass } \\
\text { Oryzopsis hymenoides (Roem. and Schult.) } \\
\text { Richer }\end{array}$ & $12.7 \mathrm{~d}$ & $10.6 \mathrm{~d}$ & $46 c$ & $38 \mathrm{c}$ \\
\hline Mulch-prairie hay & $4.0^{2}$ & 6.5 & & \\
\hline
\end{tabular}

' Mean values followed by the same letter are not significantly different at the $5 \%$ level of probability according to the Student-Newman Keul Test.

2 Stand density results from seeds contained in mature prairie hay. These means were not included in statistical analysis. of prairie sandreed and its adaptability to the environment of the blowout areas enabled this species to become established and spread rapidly and to more quickly and completely produce a cover on the bare sand.

Among the cool-season grasses, intermediate wheatgrass attained the greatest stand density, but was second to western wheatgrass in frequency of occurrence in the 1976 season and lower in frequency of occurrence than both western and crested wheatgrass in the 1977 season. No significant differences in the amount of sand moved in each plot were evident when the wheatgrasses were compared. Indian ricegrass had a low stand density and frequency of occurrence and offered the least protection to the soil, as evidenced by the amount of sand moved under its cover (Tables 1 and 2).

Comparison of species among both warm-and cool-season grasses suggests that those grasses that are most vigorous in the environment of the blowout attained the greatest stand density and frequency of occurrence. The more vigorous growth under the conditions of the blowout led to a greater protection of the surface from the erosive effect of the wind and a consequent lower amount of sand movement.

The grasses most effective in holding sand in place were prairie sandreed and intermediate wheatgrass. Among warm-season grasses, the advantage of prairie sandreed was especially apparent when amounts of sand removed from the plots following the time the grasses became established were compared (Table 2). Sand lovegrass and sand bluestem were the same in this respect and more effective in controlling sand removal than was little bluestem. Here again the more vigorous species had the advantage. The vigor of prairie sandreed under these conditions is probably due to the large number of rhizomes which it usually produces.

Among cool-season grasses, less sand moved under the wheatgrasses. When total sand movement was compared, little difference between the three species of Agropyron was evident. Yet, when sand removal only is considered, intermediate wheatgrass was better able to hold the sand down than crested wheatgrass. Indian ricegrass was least effective in the control of sand movement. Again, the advantage lies with the more vigorous species that could rapidly produce a stand 
Table 2. Mean amount of sand removal, sand added and total sand movement (metric tons/ha) in blowouts (replicates) seeded to different grasses.

\begin{tabular}{|c|c|c|c|c|c|c|}
\hline \multirow[b]{2}{*}{ Grass Species } & \multicolumn{2}{|c|}{ Added } & \multicolumn{2}{|c|}{ Removed } & \multicolumn{2}{|c|}{ Total } \\
\hline & $\begin{array}{l}\text { April 76- } \\
\text { May } 77\end{array}$ & $\begin{array}{l}\text { July } 76- \\
\text { May } 77\end{array}$ & $\begin{array}{l}\text { April 76- } \\
\text { May } 77\end{array}$ & $\begin{array}{l}\text { July } 76- \\
\text { May } 77\end{array}$ & $\begin{array}{l}\text { April 76- } \\
\text { May } 77\end{array}$ & $\begin{array}{l}\text { July } 76- \\
\text { May } 77\end{array}$ \\
\hline \multicolumn{7}{|l|}{ Warm Season } \\
\hline Prairie sandreed & 401 & 214 & 516 & 225 & $917 \mathrm{c}$ & $439 c^{1}$ \\
\hline Sand bluestem & 416 & 108 & 959 & 481 & $1377 \mathrm{~b}$ & $589 \mathrm{~b}$ \\
\hline Sand lovegrass & 286 & 63 & 949 & 558 & $1235 \mathrm{~b}$ & $621 b$ \\
\hline Little bluestem & 354 & 50 & 1243 & 765 & $1597 \mathrm{a}$ & $815 a$ \\
\hline \multicolumn{7}{|l|}{ Cool Season } \\
\hline Western wheatgrass & 418 & 134 & 756 & 356 & $1174 b$ & $490 \mathrm{~b}$ \\
\hline Crested wheatgrass & 389 & 112 & 797 & 437 & $1186 b$ & $549 b$ \\
\hline Intermediate wheatgrass & $\dot{549}$ & 232 & 583 & 252 & $1132 b$ & $484 b$ \\
\hline Indian ricegrass & 347 & 29 & 1169 & 749 & $1516 a$ & $778 a$ \\
\hline Mulch-prairie hay & 734 & 382 & 0 & 0 & $734 d$ & $382 d$ \\
\hline
\end{tabular}

'Mean values followed by the same letter are not significantly different at the $5 \%$ probability level according to the Student-Newman Keul Test.

density sufficient to keep sand movement at a low level.

None of the grass species were as effective in controlling sand movement as was the mulch. Hay used in mulching contained seeds of various grasses and other species native to Sandhills rangeland. Natural seeding from these grasses led to the stand density reported in Table 1. The effectiveness of mulch in controlling damage to the land surface by wind agrees with results reported by others (Chepil et al. 1963; Behimaya et al. 1974; Woodruff et al. 1974). In this study, the sand that moved under mulched treatment was all deposited on the plots while none was removed (Table 2). Apparently, the mulch protected the soil surface while acting as a barrier to reduce wind energy at the surface and allow sand particles to fall from suspension.

Table 2 further illustrates the value of mulch in controlling wind erosion in blowouts. Sand removal from the plots during April 1976 to May 1977 includes that part of 1976 before grasses were established on the plots, and during the time of strongest, most erosive wind in the area. Sand removal per hectare was, in most cases, nearly twice that of the July 1976 to May 1977 period. By July, the grasses were established and the northwesterly winds of spring had abated. When the strong winds came again in the spring of 1977, the established grasses were able to hold the sand with a degree of effectiveness relating to their stand density. During either period, however no sand was removed.

Sand removal from seeded plots occurred mostly from April through July of 1976 prior to establishment of grasses and from February to May 1977. Practically no movement of sand, either added or removed, occurred from August 1976 to February 1977. Therefore, the speed with which the grasses became established was a critical factor in the amount of sand moved from the plots. In late summer, vegetative density was adequate to hold sand in place. In late fall and early winter, the residues, along with typically more moisture in the soil and lower velocities of winds, kept sand removal to a minimum. In late February and March, spring winds again began to move sand. During this period, as in July 1976, there was a difference between grass species in ability to hold sand in place.

Analyses of the soils indicated that all were very sandy with very fine sand as the dominant particle size. However, all contained clay in an amount between 5.1 and 7.0 percent. Soils at the site were earlier considered to be within the Valentine Soil Series (Typic Ustipsamment) (Yost et al. 1968) but have more recently been placed within the Valent Soil Series (Ustic Torripsamment) (Soil Survey Staff 1972). Soils were alkaline ( $\mathrm{pH} 7.7$ to 8.2 ), low in cation exchange capacity (5.9 to 8.2 $\mathrm{meg} / \mathrm{l00 \textrm {g }}$ ), and low in organic carbon $<0.2 \%$ in most replicates). Calcium was the dominant ion on the exchange complex. Illite was the dominant clay mineral in the clay fraction with lesser amounts of montmorillonite, kaolinte, and quartz evident. The sand fraction was dominated by quartz with between 12.5 and $19.1 \%$ potassium feldspars and between 7.1 and $11.6 \%$ plagioclase feldspars. A measureable amount of chorite was evident in all samples. The remainder of the sand fraction was composed of heavy minerals of which the micas, amphiboles, and pyroxenes constituted the major part.

Sand movement was correlated significantly with organic matter $(r=-88$ and -84 for warm-and cool-season experiments, respectively). In the coolseason grass plots, a significant negative relationship existed between cation exchange capacity and sand movement $(r=-88)$. Percentage of clay was significantly correlated with organic matter content $(r=+.83$ and +.92 for warm-and cool-season experiments, respectively).

\section{Conclusions}

In spite of the relationship of some soil properties to the amount of sand movement, the major factor related to the control of wind erosion in the blowouts was the amount of cover on the sand and how quickly it became established. A definite advantage was noted for the grasses that produced more vigorous growth in the environment of the Sandhills, particularly prairie sandreed, as well as western and intermediate wheatgrass. Even under the cover of these grasses however, from 225 to 356 metric tons/ha of sand was removed from the plots. This amount of sand moving in the wind often buries or abrades seedlings that have become established.

Since mulched plots appeared to lose no sand, the most reasonable procedure to use in revegetating the blowout after it is shaped is to apply a prairie hay mulch containing a large number of seeds from the species mentioned. If this is not available, any type of mulch underseeded with prairie sandreed or intermediate wheatgrass appears to have considered potential for the control of blowouts in the rangeland of the Sandhills in Nebraska and surrounding states.

\section{Literature Cited}

Armbrust, D.V., and J.D. Dickerson. 1971. Temporary wind erosion control; cost and effectiveness of 34 commercial materials. J. Soil Water Conserv. 26:153-157.

Bagnold, R.A. 1941. The physics of blown sand and desert dunes. Methuen and Co., Ltd. London, England. 265p.

Baver, L.D., W.H. Gardner, and W.R. Gardner. 1972. Soil Physics, 4th edition, John Wiley and Sons, Inc. New York, 498 p.

Behimaya, C.P., E. Owtadolajam, and M.J. Malakouti. 1974. Sand dune fixation in Khuzistan Province; the efficiency and economics of different treatments. Res. Inst. 
of Forests and Rangelands, Tech. Rep. No. 14. Tehran, Iran 39p.

Chepil, W.S., and N.P. Woodruff. 1963. The physics of wind erosion and its control. Advan. in Agron. 15:211-302.

Chepil, W.S., and N.P. Woodruff, F.H. Siddoway, and D.V. Armbrust. 1963. Mulches for Wind and Water Erosion Control. U.S. Dep. Agr. ARS 41-84, Kansas Agr. Exp. Sta., No. 801. Manhattan.

Drullinger, R.H., and B.L. Schmidt. 1968. Wind erosion problems and control in the Great Lakes region. J. Soil Water Conserv. 23:58-59.
Eck, H.V., R.F. Dudley, R.H. Ford, and C.W. Gantt, Jr. 1968. Sand dune stabilization along stream in the southern Great Plains. J. Soil Water Conserv. 23:131-135.

Jackson, M.L. 1956. Soil Chemical Analysis, Advanced Course Published by the author, Dept. of Soils. Univ. of Wisconsin.

Seevers, P.M., D.T. Lewis, and J.V. Drew. 1975. Use of ERTS-1 imagery to interpret the wind erosion hazard in Nebraska's sandhills. J. Soil Water Conserv. 30:181-183.
Soil Survey Staff. 1972. Soil survey laboratory methods and procedures for collecting soil $\mathrm{s}$ samples. Soil Survey Investigations. Rep. No. 1. S.C.S, U.S. Dep. Agr. Washington, D.C. Woodruff, N.P., Lyles, J.D. Dickerson, D.V. Armbrust, 1974. Using cattle feedlot manure to control wind erosion. J. Soil and Water Conserv. 29:127-129.

Yost, D.A., D.L. Brown, L.L. Buller, and J.O. Olson, 1968. Soil survey of Scottsbluff Co., Nebraska. U.S. Dep. Agr. S.C.S., Publication. Special Rep. 